Research Article

\title{
Future Situation of Northern Nigeria from Poetic Mirror: The Outstanding Prophesiers from Hausa Poets
}

\author{
Dr. Yahaya IDRIS ${ }^{1}$, Abu-Ubaida SANI ${ }^{2}$ \\ ${ }^{1}$ Department of Nigerian Languages Usmanu Danfodiyo University, Sokoto \\ ${ }^{2}$ Department of Educational Foundations Usmanu Danfodiyo University, Sokoto
}

\begin{abstract}
Since the early ages of modern socialization amongst the Hausas, i.e. learning to read and write, poetry had been a good instrument used in educating, enlightening, orienting and passing across important messages among host of related others. Most of the early Hausa poet were knowledgeable, who had sound experience of the national affairs. They were also critical thinkers, so skeptical about the present and zealous of foreshadowing the future. They sometimes warned humanity on the dangers they forecasted, urging peoples to change attitudes for better. Against this background, this paper traces a number prophesies made by some Hausa poets, which have turned realistic. The poet forecasts some disastrous outcomes to loom Northern Nigeria, shall the Northerners dare not to cease certain attitudes and some bad practices. This paper traces the instances of such prophesies made by poets, which are obviously realistic today. The study is limited to three selected poems viz: AJM, TSW and MAHRKW. However, the study found that, a number of prophesies made by the selected Hausa poets in forms of warning and or alarms have been realized. Finally, the paper tabled some suggestion among which one is, that reading and listening to poems should aimed beyond mere passion of its tranquil nature. There teachings should rather be carefully studies and fittingly utilized.
\end{abstract}

Keywords: Northern Nigeria, Hausa, Poets, Poems, Prophesy

\subsection{Introduction}

Poetry is an effective instrument for national development and promotion of self and national consciousness. The tranquil nature of literature attracts greatly the attention of individuals. Messages passed through poems barely are in vain, for people to read or listen to them even just for pleasure. Poems, among other literary works, in many cultural groups are held with great esteem. People from such populations gain self-esteem by seeing themselves represented in books, poems, and folktales among other literary works. Thus, people begin to appreciate others from culturally diverse backgrounds (Roe, \& Ross, 2010).

Usman, (2009) considers poetry as the peak of human philosophical expressions, which have greater influence on the human mind. In contrast, the Northerners seemed to have being giving deaf ears to the alarms of premonitions being raised by Hausa poets among others. The paper selected three poems as references in this regard. They are:

Wakar Arewa Jamhuriya ko Mulukiya (AJM) of Sa'adu Zungur

Wakar Tutocin Shehu da Waninsu (TSW) of Mu'azu Hadeja Wakar Muhimmancin Al'adunmu: Hadarin Rungumar na Kasashen Waje (MAHRKW) by Alkali Haliru Wurno

The paper is interested in finding answer to the following questions:

i. What are those prophesies being made by the Hausa poets on the future of the Northern Nigeria?

ii. Are such prophesies ever realized?

2.0 Brief about the Poets
The paper selected three poets, from whose poems relevance instances are cited. This session of the paper accounts for a brief discuss on the poets; viz; Malam Sa'adu Zungur, Malam Mu'azu Hadeja and Alkali Haliru Wurno:

\subsection{Malam Sa'adu Zungur}

Malam Sa'adu Zungur who was a very prominent public figure was an indigene of Bauchi State, Nigeria. He came from a renown knowledgeable family. He attended Katsina College and was the first Northerner college graduate to be sent to higher college based at Yaba, Lagos. In fact, he was a key figure in the politics of Northern Nigeria. Since around 1940, he organized and delivered a lecture at Zaria on the relevance of political parties, which led to the emergence of one of the first Nigerian political parties notably Zaria's Friendly Society.Moreover, he was one of the founders of northern Nigerian academic staff political party. He first traveled to England on political issues since around 1947 when politics was a new phenomenon in Nigeria. However, Malam Sa'adu Zungur had written several poems, which are mostly political.

\subsection{Malam Mu'azu Hadeja}

Malam Mu'azu Hadeja was born in the 1918 at Kilabakori, Hadejia of Jigawa State, Nigeria. He obtained adequate parental rearing with good Islamic orientation. He was taken to a traditional Qur'anic school in his early years. Mu'azu was young when formal education was introduced to northern 


\section{Hausa Poets}

Nigeria around 1910. As such, he attended Elementary school called Dalla at Hadejia between1935-1937. He did not abandon the pursuit of Islamic education while in the formal school system. Rather, he conjointly pursued the two knowledges.

However, Mu'azu was appointed a teacher at Wudil Elementary School in the 1938 where he had been teaching until in the 1940. From 1944 to 1947, he became Teacher in Charge (IC). He also taught at Katutu Elementary School, Ringim from 1944 to 1947 . Mu'azu was transferred to Kano as a visiting teacher by the 1947 . He worked on this position up to 1958 when he died. During his time, he had written voluminous poems, which are mostly educative.

\subsection{Alkali Halur Wurno}

Alkali Harilu Wurno was born in the 1925 in a village called Kwargaba, Sokoto State. He attended Qur'anic school, Makarantar Malam Maccido, in Sokoto at his younger age. He later attended a law school at Sokoto between 1943 and 1947. Later, he moved to sharia school at Kano where he graduated in the 1951. He studied voluminous literatures especially in the field of sharia law.

Wurno taught in Elementary School Maru for one and half a year. Subsequently, he picked an appointment with ministry of sharia and justice in Sokoto, that was around 1952 to 1965. In the 1965, he decided rejoining the educational sector, in which he picked job with a school named Nizamiyya in Sokoto. It was during this period of service that he wrote one of his famous poems, Fanda ko Danja, explaining the terrible accidence he had together with his brother, Muhammad Lema. After sometimes, Wurno was appointed a judge at Sokoto. He worked in the sharia sector until 1981 when he willingly retired. Finally, he died in the year 2003. During his life time, he had written voluminous poem, as he picked poetry since at his 5 years.

\subsection{Traces of Prophetic Alarms from the Selected Poems}

The three poets, among other Hausa poets however, had bitterly raised several alarms of concern regarding the attitudes of the Northerners. They expressed a strong premonition, which are obviously subject to certain attitudinal practices of the Northerners. This include thirst for migration, negligence to religion, dishonesty, corruption in politics and leadership as well as other immoral acts, which include prostitution, transgender, and greediness among others. These could be discussed under the following subheading:

\subsection{Dis/Honesty in Politics and Leaderships}

In Arewa Jumhuriya ko Mulukiya, Sa'adu Zungur pointes that, dishonesty and corruption in leadership brings about disintegration and turns societies ungovernable. He says:

29. Shehu Abdullahi hakikatan, Ya bar mana gadon gaskiya. Shehu Abdullahi (has) undoubtedly, Bequeathed to us the legacy of truth.

30. Ilimi, hikima addini duka,Da dabarar sarrafa duniya.
Knowledge, wisdom and religion,And the skills to manipulate the world.

31. Muka lalata, muka wargaza,Ga shi yau sai a nai mana dariya.

We despoil and scattered (them),Today we have become laughing stock.

32. Babu tsuntsu ba tarko duka,Wallah mun yi hasarar duniya. No birds and no snare - all lost,By God, we have lost the world!

52. Kar ka bar arna su shige musu,Don su watsa dafin Jumhuriya.

Never allow infidels to penetrate them,And spread the Republican poison.

54. In ji dai kun hangi mutan Gusun,Masu mai da Kasa Jumhuriya.

I hope you have espied the southerners, Who transform a country into a Republic.

(Wakar AJM ta Sa'adu Zungur in Yakubu, 1999: 336-364)

In other stanzas of the poem, he calls upon traditional leaders to promote justice and that they should be alerted on the missions of some individuals southerners who are ready for the disintegration of the country at all cost. He also emphasizes that, leaders shall be considerate on the interest of their subjects. He says:

97. Hakkin jama'a na kansu duk,Su rike igiyarsa da gaskiya. Responsibility of the people is on them, all,They should hold fast the rope with unity.

98. In kunka sake jama'ar Kudu,Suka hau mukin Nijeriya. If you allow the Southerners, To come to power in Nigeria-

99. Dada ba sauran mai tambaya,Kowa ya san zai sha wuya. Surely nobody will ask any more question, Every body knows that he will suffer!

100. An sha bamban bisa kan nufi, Na shirin mulkin Nijeriya. Our intentions are different,For the purpose of ruling Nigeria.

107. Fatarmu Arewa ta farga duk, Don ta gane lamarin duniya.

Our hope is that the North awakes instantly, And understand worldly affaires.

108. Farfaganda makirci duka,Sai a bar ta, a binciki gaskiya. All deceitful propaganda, Should be ignored and the truth sought after.

(Wakar AJM ta Sa'adu Zungur in Yakubu, 1999: 336-364) It is obvious that these prophecies are realized. History shall never forget the deadly activities of Boko Haram sect in the Northern Nigeria. Though their activities started since around 2007 when a Northerner was the Head of State, it did not metamorphose until around 2011 when a Southerner was handling the mantle of power. Hamza, (2012) associated government's movements during the Boko Haram crises as conscious attempt for the destabilization of the North. Hence, the crises continued, leading to lost of lives and properties, 


\section{Hausa Poets}

until around 2015 when a Northerner became the Head of State.

Similarly, Mu'azu calls upon leaders thus, they shall maintain judicious treatment of their subjects, as they mean everything to them (to their subjects). He points out that, without a good leadership, there would never be good followership. This is because, leadership determines the attitudes of followers towards it. He says:

37. Ku kunnuwanmu ne ku san, Ku ne idanunmu ku san, Ku ne kafafunmu ku san, Ku bakunanmu ne ku san,Wuyanku munka rataya.

You are our hearing, beware, You are our seeing, beware, You are our movements, beware, You are our voices, beware,We rely on you.

38. Inda baki ya karkata,Ta nan miyau shi kan fita,In ka ga kyalla ta Бata,Mai bin ta ne ya sake ta,Kafarta babu igiya.

When a leadership is faulty,Society turns ungovernable,If things fall apart,Leaders were careless, They allowed lawless society.

(Wakar TSW ta Muazu Hadeja)

\subsection{Cultural Controversies}

Alkali Haruna Wurno opines that, differences in cultural practices is the backbone of pandemonium, which brings about unease atmosphere between the Northern and the Southern parts of the country. He holds that, the best precaution against being oppressed is for the Northerners to remain in the North where they could freely practice their good cultures. This is to prevent chaos and to safeguard individuals'lives and properties. Recently, on the $9^{\text {th }}$ January 2018, an online Nigerian newspaper (Naija News) reported Nigerian police confirming the killing a NYSC member at Akwa Ibom State (Abiola, 2018). Earlier on the $15^{\text {th }}$ December 2017, the Sun News reported how a confession of a murderer on raping and killing NYSC member at Ogun State (Raheem, 2017). In this regard, Alkali Haruna Wurno says:

7. Gidan wasu ba gidanku ba ne ka gane,Uwar wasu ba uwarka ba ce ka bar ta.

Beware that strangers' home is never yours, One man's food is another man's poison, let it go.

8. Garin wasu ba garinku ba ne ka lura,Zaman Gumi bai kama da zaman su Delta.

A strange town is never like yours, beware,Life at Gummi differs from life at the likes of Delta.

(Wakar MAHRKW ta Alkali Haruna Wurno)

Using similar stanzas, Sa'adu Zungur warns the Northerners to stay within the North and strive for its development and that they should never follow propaganda of some unscrupulous individuals who wish for the disintegration of the nation. He says:

125. Kar ku rudu da zancen ja'irai,Masu son halakar Nijeria. Never be deceived by the words of dare devils, Who want the destruction of Nigeria.
130. 'Yan Arewa ku daina gaganiya, $\mathrm{Ku}$ rike daularku da gaskiya.

O, Northerners, stop wrangling, And hold your domain with sincerity.

135. In kun dage, kun shantake,Bisa al'adu na mazan jiya.

If you are heedless and procrastinate, In adhering to the olden customs.

136. Za ku rera fadar da-na-sani,Da na bi jawabin gaskiya. You will chant "Had I known - I would have accepted the true advice."

(Wakar AJM ta Sa'adu Zungur in Yakubu, 1999: 336-364)

On a similar note, Mu'azu Hadeja was baffled by the situation in which some Northerners are deceived and influence politically to wholeheartedly accept the political and sociocultural mutuality with the Southerners, theground on which they (the Northerners are oppressed). He says:

45. Ka ji abin mamaki,Ungulu zai kasha maiki, Dawa za ta ci doki,Kare yi sannu da zaki,Don juyi na duniya.

What a surprise!Vulture will kill an eagle, Grains feed on horse, A dog associates with a lion, (All) as a result of the changing world.

52. Abin ga ko da gaskiya?Kura ta iske tunkiya,Ta ce su je su tsariya,Akwai tuwo akwai miya, Su yi shagali na duniya.

Isn't it a deception? (For) a hyena to invite a goat,

That they go to a picnic, Where all sort of foods are available, So that they enjoy together.

\subsection{Religious Zealousness}

Northern Nigeria is predominantly occupied by the Hausas (Musa, 2013) However, majority of the Hausas practice Islamic religion. Only a small percentage of Hausa people known as Maguzawa (pagans), practice religions other than Islam (ALS, 2015). Moreover, larger population of most of the other tribes residing in Northern Nigeria are Muslims. As such therefore, Islam could be regarded as the religion of Northern Nigeria. Sani \& Tsaure, (2016) consider religion as a manual of life. Thus, Allah knows best, and that is only by acting in accordance to religious teachings, there would never be peace. Sa'adu Zungur has pointed similar situation, warning the Northerners that, shall they abandon Islamic teachings, misery would loom the land. He says:

38. In fa addini ya raunana,Babu alheri nan duniya.

(For) if religion is neglected,There is nothing good in this world.

48. Sai arnanci ya yi sallama,Dada har abada ba dawaya. Infidelity then surface, Never again to return.

(Wakar AJM ta Sa'adu Zungur in Yakubu, 1999: 336-364)

\subsection{Antisocial Practices and or Attitudes}

Immoral acts such as prostitution, hooliganism as well as alcoholism and drug addiction are considered highly antisocial and against the cultural norms of Northern Nigera. Sa'adu Zungur strongly points at some of these practices warning against them. He emphasizes that, shall the Northerners dare 


\section{Hausa Poets}

not to listen, the result must surely be calamitous. He says:

141. Matukar a Arewa da karuwai,Wallah za mu yi kunyar duniya.

As long as there are prostitutes,By God we shall suffer worldly shame.

142. Matukar 'yan iska na gari,Dan Daudu da shi da Magajiya.

As long as there are hooligans in town,transgender and the influential brothel lady -

143. Da samari masu ruwan kudi,Ga maroka can a gidan giya. And young men who shower money,To praise singers in beer houses -

144. Babu shakka 'yan Kudu za su hau,Dokin mulkin Nijeriya.

Surely the Southerners will mount,The horse of Nigerian leadership.

145. Su yi ta kau sukuwa bisa kanmu ko,Mun roki zumuntar duniya.

And they will be galloping without remorse over us, Even if we beg for mercy.

\section{(Wakar AJM ta Sa'adu Zungur in Yakubu, 1999: 336-364)}

Mu'azu Hadeja says in some similar stanzasof his poem:

50. Ga shi muna son mulki,Tsaninmu babu mataki, Zancen awa na mafarki,Auren da babu sadaki,Yana cikin haramiya. We have thirst for power, Yet, we lack the requirements, It is more of a false dream,Like are marriage without dowry, That is an abomination.

51. Kasarmu ba masu sani,Idommu ma ba su gani,Mu bar ${ }^{\text {a. }}$ shiga zugar wani,Da hankali da tunani,Kadda mu koma baya. Our land lacks knowledgeable people, We are even blind,Lets not be influenced by propagandas, Lets be rational and thoughtful,So that we do not retrogress.

65. Ana zato za a iya,Watakila za a sha wuya,Don karya dad. gaskiya,Ba su zama wuri daya,Kan Kauli na gaskiya.

It is assumed ordinarily simply,It may be a total torture,

Because honesty and falsehood, Are never practiced at a time, In the name of justice.

(Wakar TSW ta Mu'azu Hadeja).

\subsection{Pessimism Versus Optimism}

Sa'adu Zungur was moved by the Attitudes of the Northerner to the extent of being pessimistic, forecasting regret as the outcome if deaf ears are given to his words. He says:

113. $\mathrm{Mu}$ dai hakkinmu gaya muku,Ko ku karБa ko ku yi dariya.

Our responsibility is to inform you,You either adhere or laugh it off.

114. Dariyarku ta zam kuka gaba,Da nadamar mai kin gaskiya.

Your laughter turns to sorrow in future,And regrets, the kind done by one who rejects the truth.
Nevertheless, both Sa'adu Zungur and Mu'azu Hadeja prayed for better and positive transformation of the North. Ainu, (2007) explains prayer as special form of request laid to God using certain distinctive statements. Sa'adu Zungur says:

16. Addu'armu ga Allah Rahimi,Ya kiyaye Arewa gaba daya. Our prayers to God the Merciful (is that)He protects the whole North.

17. Muminai da Masihai jumlatan, Kuma arna dodannin gida. Muslimss and Christins all,And the infidels, the goblins.

107. Fatarmu Arewa ta farga duk, Don ta gane lamarin duniya.

Our hope is that the North awakes instantly, And understands worldly affairs.

(Wakar AJM ta Sa'adu Zungur in Yakubu, 1999: 336-364)

On the other hand, Mu'azu Hadeja makes a similar prayer but on the condition that if only the leaders are judicious. He says:

39. Allah muna a gare ka, Mun ko fage a gare ka,Muna bidar ka taimaka,Sarakuna su daukaka,In sun tsaya wa gaskiya

Oh God! We are submissive to you, And we defended on you,

We pray for your help,(That) our leaders excel, If they hold onto justice.

(Wakar TSW ta Mu'azu Hadeja)

\subsection{Findings of the Study}

From the instances in the three poems as given above, the study understood that:

i. Hausa poets have been prophesizing on issues, of which some are:

Dishonesty and corruption by Northern political leaders will insure but the downfall of the land.

The Northerners would face oppression when on the Southern land.

c. The North should await more dangers shall religious teachings be neglected.

With the presence of some antisocial practices and or attitudes, there shall never be peace in the North.

ii. The current situation of the Northern Nigeria is just as being predicted by some Hausa poets. The present insecurity, high level of corruption, economic setback and increase in social vices in the Northern part of the country have been prophesized by such poets in their various educative and enlightening poems.

\subsection{Conclusion}

If effectively utilized, it would be interesting how significantly Hausa poetry could help in promoting national integration, sound morally oriented community and reduces all sorts of social vises to a very minimum level. As a media, it stands opportunity to be used in passing moral, cultural, political to mention but some, messages with regard to integration (as well as other phenomena associated with politics, economics and religion among others). It could be seen from the stanzas quoted above, factors hindering mutual coexistence and lawful society. Therefore, is a challenge to government and educators 
to maximize this opportunity. Perhaps, Hausa poems of this type should be appropriately incorporated in the school syllables so that their messages are best unsterilized.

Against this background, the following are hereby suggested:

1- Teachers and other educational personals should bear in mind that poems help forge a mass of people into unified society. However, they provide awareness on traditional attitudes and values of different cultural groups. That helps in knowing the culture and traditional practices of one another, thereby promoting mutual respect.

2- Teachers should guide students to generate principles and their applications from the various poems to real life situations.

3- Teachers should be guiding students to be able to have integration of the theoretical studies (poems) with practical examples (real life situations).

4- While dealing with poetry (Hausa poetry in particular), rote learning should be discouraged. Without understanding the contest, there cannot be transfer of learning (from the poem to real life situation). Nonetheless, reading and listening to poems should aimed beyond mere passion of its tranquil nature. There teachings should rather be carefully studies and fittingly utilized.

\section{References}

[1] Abiola, O. (2018). Police Confirm Killing Of NYSC Member In Akwa Ibom. Retrieved on $2^{\text {nd }}$ March, 2018 from: https://www.naijanews.com/news/41309-policeconfirm-killing-of-nysc-member-in-akwa-ibom/

[2] Accredited Language Services (ALS), (2015). Hausa. Retrieved on 15 October 2016 from: https://www.alsintl.com/

[3] Ainu, A. H. (2007)." Rubutattun Wakokin Addu'a na Hausa: Nazarin Jigoginsu da Salonsu.” Kundin Digiri na Uku. Sakkwato: Sashen Nazarin Hasunan Nijeriya, Jami'ar Usmanu Danfodiyo.

[4] CNHN. (2006.) Kamusun Hausa na Jami'ar Bayero ta Kano. Zaria, University Perss Ltd.

[5] Hadeja, M. (1955) Wakokin Mu'azu Hadejia. Zaria, N N P C.

[6] Hamza, I. M. (2012). Nigeria: Boko Haram-State of Emergency Meant to Attack Muslims. Retrieved on $1^{\text {st }}$ March 2018 from: http://allafrica.com/stories/201201030834.html

[7] Idris, Y (2013) Falsafar Zaman Duniya a Wakar Duniya ta Yusuf Kantu Isa A Cikin Zauren Waka Mujallar Nazarin Wakokkin Hausa. Vol 1 no 1 Sakkwato: Sashen Nazarin Harsunan Nijeriya, Jami’ar Usmanu Danfodiyo.

[8] Musa, M. A. (2013). The importance of Hausa language as a verbal communication to Hausa people. Retrieved 23 December 2016 from:
[9] Omar, S (2013). "Fasahar Mazan Jiya: Nazari a Kan Rayuwa da Wakokin Malam Mu'azu Hadejia.'Kaduna, Garkuwa Media Services Ltd.

[10] Raheem, A. (2017). How I raped and killed corps member -Suspect. Retrieved on $2^{\text {nd }}$ March, 2018 from: http://sunnewsonline.com/how-i-raped-and-killed-corpsmember-suspect/

[11]Roe, B. D. \& Ross, E. P. (2010). Benefits of Literature. Retrieved from, www.education.com

[12] Sani, A-U. \& Tsaure, M. B. (2016). An Image of Northern Nigeria's Marital and Gender-based Controversies: A Survey of Abubakar Gimba's Sacred Apples. Being a paper presented at the $13^{\text {th }}$ International Conference on Ethnic Nationalities, Cultural Memory and the Challenges of Nationhood in $21^{\text {st }}$ Century Literature, held at The University Auditorium, IBB University, Lapai, from $30^{\text {th }}$ August to $2^{\text {nd }}$ September 2016.

[13] Yahya, A. B. et al. (2014). "Gyara ko Banna, Matasa ku yi Hattara: GurБata Wakar Arewa Jimhuriya ko Mulukiya Cikin Jerin Littatafan N.N.P.C. Takarda da aka Shirya don Taron Kasa da Kasa domin tunawa da Marigayi Farfesa Muhammad Hambali Junju da Kungiyar Marubuta Cikin Harshen Uwa ta shirya Yamai jamhuriyar Nijar.

[14] Yakubu, A. M. (1999). Sa'adu Zungur: An Anthology of the Social and Political Writtings of a Nigerian Nationalist. Kaduna Nigerian Defence Academy Press. http://linguistmam.blogspot.com.ng/2013/04/theimprotance-of-hausa-language-as.html 